\title{
Wat hoort tuis in 'n kerkwet of kerkorde in die lig van die Skrif en die belydenis?
}

\author{
AD Pont
}

\section{Inleidende opmerkings}

Dit is duidelik dat hierdie vraag 'n uitgebreide antwoord kán ontlok, aangesien dit ook gesien kan word as die vraag: Hoe moet die kerk op aarde se sigbare orde of organisasie volgens Skrif en belydenis wees?

In die tweede plek is dit duidelik dat nie alles wat in 'n kerkwet staan en moet staan, direk terugvindbaar is of kan wees in Skrif en belydenis nie. Elke vormgewing van die kerklike orde is altyd ' $n$ vermenging van goddelike èn menslike reg. Tog is dit waar dat die primêre beginsels wat vir die kerklike orde en regering bestaan, in die Nuwe Testament self gegee word èn in die geloofsbelydenis aangedui en omlyn word. Die kerklike ordening is, om dit so te stel, dus niks anders as 'n uitwerking in en vir die praktyk van die hooflyne wat deur die belydenisskrifte getrek word en wat uit die Skrif afgelees word nie.

Om dit so te stel, is die bronne vir ons kerklike reg die Skrif, die belydenis, die uiteensetting, binne die teologiese ruimte van die belydenisskrif, van die ekklesiologie èn dan ook die "voortdurende gewoonte" (Wezel 1568) vir sover daardie "voortdurende gewoonte" ofte wel die sinodale beslissings van die verlede bepáál is deur die Skrif en die riglyne wat die belydenis trek. Dit bring mee, wat ons kerk betref, dat die 19de-eeuse kerklike reg krities beskou moet word. In die algemeen gesien kan immers gestel word dat daardie kerkreg nié sy beginsels uit die Skrif put nie, maar uit die sogenaamde natuurlike reg en die redelike denke van die mens. Dit beteken dat die vraag gestel moet word of die opvolging van vergaderings, soos dit in ons kerk gevind word, werklik verantwoord kán word in die lig van art 31 NGB èn die Skriftuurlike gegewens waarop dié artikel gebou is.

Aan die ander kant is dit ' $n$ vraag of die hele leer van die verbond, die basiese struktuur van die genade (Van Ruler), wat die agtergrond van die belydenisskrif en die Calvinistiese presbiteriaal-sinodale kerkorde vorm, genoegsaam en duidelik in ons kerklike ordes verdiskonteer word.

Die volgende sake word hier net aangestip en kortliks behandel. 


\section{Jesus Christus, die Hoof en Heer van die kerk}

Art 31 van die NGB noem Jesus Christus "die enigste algemene Opsiener én die enigste Hoof van die Kerk". Hierdie stelling wat normaalweg nié in die kerklike ordes as sodanig voorkom nie, is egter die uitgangspunt van die kerklike ordening. Een van die primêre vrae van die kerklike ordening is hoe om hierdie feit dat Christus die enigste hoof van sy kerk is, volledig te verdiskonteer.

Normaalweg word dit gedoen deur:

(a) Die erkenning dat die Woord van God die eerste en laaste gesag in die kerklike lewe is. Met ander woorde - die amp, die vergaderings en sy besluite, die lewe van die gelowiges moet bepáál word, genormeer word, inhoud gegee word deur die Woord alléén - vergelyk artikel 29, NGB.

(b) Die afsnyding van elke vorm van hiërargie in die kerk - dit wil sê 'n hiërargie van ampte, van vergaderings of van verhoudings wat die indruk skep dat daar ' $n$ mens of 'n vergadering of ' $n$ reëling is wat die indruk skep of ook daadwerklik Christus as enigste Hoof van die Kerk verdring.

Daar kan dus, in die kerklike orde, nié iets verdra word wat plaasvervangend vir Jesus Christus optree nie, soos die pous in die papale sisteem of die sinodale vergadering in die kollegiale sisteem nie - vergelyk artikel 29, NGB.

(c) Die erkenning dat álle gesag in die kerk die gesag van Jesus Christus is èn moet wees. Die gesag van die amp of die vergaderings van die ampte is en bly sekondêre gesag - artikel 27, NGB.

\section{Die ampte}

Dit is miskien goed om wéér daarop te let dat die amp 'n dienswerk (ministerium) is en nié ' $n$ vooraanstaande of hoë gesagsposisie (officium) in die kerk of gemeente nie. Vir 'n verstaan van die amp en vir 'n "ampsleer" is Efesiërs 4:11-12 die grondliggende uitgangspunt. Daar is géén twyfel daaroor dat die diens of amp suiwer Skriftuurlik is nie. Die amp is daar ter wille van die regering van die kerk (art 30, NGB). Gewoonlik word gestel dat Jesus Christus sèlf direk sy kerk deur sy Woord en Gees regeer en indirek, middellik deur die amp.

Daar kan seker 'n mate van verskil wees oor die vraag of die ampte-dienste, soos ons hulle handhaaf, gegrondves is op die drie ampte van Christus èn of ons ons ampte moet herlei uit die oer-amp of diakonia van die apostel. Dan sou dit dus drie funksies van die één amp wees. Verder sou mens 'n diskussie kan voer oor die vraag of ons ampte-dienste van teologiese professor, predikant, ouderling 
en diaken presies dieselfde is as die Nuwe-Testamentiese dienste wat as sodanig aangedui word. Tog hoef daar nie enige twyfel te wees oor die vraag of die primêre elemente van die ampte-dienste soos ons dit omskryf het, ooreenkomstig die Heilige Skrif is of nie.

'n Moment ten opsigte van die amp wat nié uit die oog verloor moet word nie, is:

(a) Skriftuurlik gesproke is die amp 'n gawe van God aan die gemeente, 'n middel waardeur die Christus-regering van die kerk voltrek word. Die amp kom dus nie voort uit die gemeente nie en die ampte funksioneer ook nie as die bestuur van die kerk soos die bestuur of bestuursvorme van die vrywillige vereniging nie. Die amp is niks meer en niks minder as ' $n$ diens ten behoewe van die Christus-regering nie, maar nooit 'n voorwaarde daarvoor nie. Christus regeer sy kerk primêr self deur sy Woord en Gees en die amp moet dit erken èn daarvolgens werk en nié daardie Christus-regering vervang of probeer vervang met 'n menslike regering nie.

Om dít moontlik te maak, is reëls deur Calvyn opgestel om dit in die kerklike orde te waarborg. Dié reëls is menslike reg, maar staan in diens van die bogenoemde beginsel. 'n Paar van die reëls is:

(i) die anti-hiërargiese klousule;

(ii) die reëling dat die amp alléén deur middel van 'n vergadering kan regeer;

(iii) die rotasiebeginsel, dit wil sê die tweejaarlikse termyn van die ouderling se diens, èn die reëling dat die leiding van die vergadering van die ampte moet roteer;

(iv) die instelling dat die bevoegdheid van die amp èn

(v) die van vergaderings begrens word deur die Woord van God.

(b) Die amp bepáál nie die kerk nie, is nie ident met die kerk nie en die kerk kán, indien nodig, sonder die amp bestaan èn voortbestaan, aangesien Christus sèlf sy kerk deur sy Woord en Gees regeer, in stand hou, lei en versorg. Die priesterskap van die gelowiges, die mondige gelowige, is in sekere sin, net so "belangrik" as die amp, want die kerk is nie daar ter wille van die kerk nie, ook nie ter wille van die amp nie, maar ter wille van die koninkryk van God. Christus gee die amp of diens in die kerk en dit moet dus, noodwendig, ten behoewe van die liggaam van Christus gebruik word.

Dit word dus betreklik gou duidelik dat die amp in die kerk ' $n$ dienswerk is. Tog is dit óók waar dat nie alles rondom die amp suiwer Skriftuurlik of direk tot die Skrif herleibaar is nie. Hier 
kan gedink word aan die proponentseksamen, die pensioenfondsreëlings, reëlings ten opsigte van traktement en so meer.

Ten opsigte van die Skriftuurlikheid van ons ampsreëlings kán daarop gewys word dat, uit die aard van die saak, die Skrif nie die figuur van die teologiese professor of 'n liggaam soos 'n teologiese opleiding ken nie. Ook is dit duidelik dat 'n hele reeks van die bepalings rondom die dienswerk van die predikant, (byvoorbeeld dat hy voorsitter van die kerkraad moet wees) die ouderling en die diaken nie as ius divinum aangemerk kan word nie. Maar die vraag is nie altyd of dit direk Skriftuurlike opdragte is en moet wees nie, maar of die reëlings ooreenkomstig die Woord van God (Calvyn) is. Baie van die reëlings ten opsigte van die dienste of ampte is suiwer ius humanum, maar dit hang saam, as dit goed is, met 'n Skriftuurlike leer van en oor die amp in die kerk.

\section{Die vergaderings}

Die algemene uitgangspunt in die presbiteriaal-sinodale tradisie is dat die amp, ten behoewe van die regering van die kerk, alléén deur middel van die vergadering van die ampte funksioneer. Dit bring soms die versugting mee wat in Nederland geformuleer is as: "Wij vergaderen tot wij tot de vaderen vergaderd worden."

Die kerkraadsvergadering en die sinodale vergadering is Skriftuurlik, veral as Handelinge 15 as die instelling van die sinodale vergadering beskou word. Dié vergaderings is daar ter wille van die regering van die kerk en om die regering en instandhouding "van die liggaam van die kerk" volgens 'n bepaalde orde te dien (vgl 32, NGB).

Oor die kwaliteit en bevoegdhede van die verskillende vergaderings en veral die meerdere vergaderings bestaan daar baie min direkte Skriftuurlike aanwysings. Dit is egter duidelik dat die kerkraadsvergadering die primêre en verantwoordelike vergadering van die ampte in die kerk is. Artikel 30 NGB dui dit so aan en gee ook die doel van die kerkraadsvergadering aan.

Artikel 32 NGB gee die doel èn die grond van die meerdere vergadering aan wat, in die lig van artikel 27 ingestel is om die eenheid-in-die-geloof-en-lewe van die liggaam van Christus, die hele kerk dus, te dien. Die meerdere vergadering, wat nié 'n lewensvoorwaarde vir die bestaan van kerk en koninkryk is nie (vgl die historiese bestaan van Genève en die Nedelandse vlugtelinggemeentes van die 16de eeu en dan veral die een te London), is daar in beginsel, as hulp- en bystandsliggame vir die kerkraad om dié sake, genoem in artikel 29, NGB, reg te doen èn om besluite, op grond van 
die Skrif alléén, te neem ten opsigte van sake soos die leer, die orde en inhoud van die godsdiensoefening èn die dissipline. In die presbiteriaal-sinodale sisteem is die werkopdrag of bevoegdheid van die meerdere vergadering baie presies omskrywe.

Dit is juis op die vlak van die meerdere vergaderings waar die 19 de-eeuse kerkreg 'n verwoestende effek op die presbiteriaal-sinodale ordening gehad het èn het. Die kerkreg met sy natuurregtelike opvattings het die parlementêre demokratiese regeringsvorm in die kerk ingedra (soos die papale sisteem ' $n$ nabootsing is van die bestuursvorm van die Romeinse Keiserryk) èn die kerkraadsvergadering verplaas na die onderkant van 'n piramidale bestuurs- en gesagsstruktuur waarvan 'n sinodale kommissie die spits van die struktuur is. Hier vind ons 'n sorgvuldige hiërargie van vergaderings met die "topstruktuur" belas met 'n algemene gesag oor die geheel van die kerk wat deur niks beperk word nie. In teorie is die Woord van God óók die grens van die gesag van die meerdere vergaderings, maar dit word, normaalweg in die 19de-eeuse kerkregtelike sisteme nêrens gestel nie. Hier geld presies dieselfde beswaar téén uitsprake van 'n sinodale kommissie as teen die Roomse sisteem waar die beginsel geld: Roma locuta, causa finita est. So word dus 'n gesagstruktuur in die kerk gebou en daarvoor word die amp gebruik wat -

(a) weinig ruimte laat vir die direkte Christusregering;

(b) die meerderheid op vergaderings finaal laat beslis (soms) in plaas van die Woord van God;

(c) die kerkraadsvergadering reduseer tot 'n onmondige, administratiewe liggaam wat die beslissings "van bo af" sonder die reg van navraag, moet uitvoer;

(d) 'n sorgvuldige hiërargie van vergaderings handhaaf en daarom ook van die (permanente) ampsdraers van dié vergaderings;

(e) die priesterskap van die gelowiges sinloos maak, want alléén die amp of die hoër vergaderings kan, in beginsel, die Skrif uitlê;

(f) die kerk sekulariseer en reduseer tot 'n genootskap wat gelykstaan aan enige ander vrywillige vereniging.

Die feit dat die meerdere vergadering èn selfs die bevoegdhede van die kerkraadsvergadering skaars in die Skrif genoem word, het juis hiér aan die 19de-eeuse kerkreg met sy a-Skriftuurlike uitgangspunte 'n maklike infiltrasiegaping gegee. Soos die Roomse sisteem op die twee bene van die Skrif èn die tradisie staan, so staan die 19de-eeuse kerkreg op die twee bene van die natuurreg èn die voortdurende gewoonte in die kerk vanaf die begin van die 19de eeu.

In die teologiese arbeid binne die ruimte van ons kerk is daar nog 
min aandag gegee aan sake soos die noodsaaklikheid en grondbeginsels van die meerdere beginsels van die meerdere vergaderings, die vraag na die ius divinum ten opsigte van die meerdere vergaderings, die karakter en kenmerke van die meerdere vergaderings en wat daarmee saamhang.

Oor die bestaan, Skriftuurlik gesproke, van die meerdere vergadering hoef nie getwyfel te word nie (art 32, NGB). Binne die ruimte van ons kerk, in publikasies en uitsprake in hierdie verband, kan min gevind word wat hieroor handel. Dit is dus 'n oop vraag of hieroor ' $n$ standpunt bestaan wat as algemeen aanvaar beskou kan word. Dit is dus moeilik om te bepaal of "die kerk" daaroor 'n ander standpunt het, as die status quo, soos omlyn in die Kerkwet en Bepalings.

Die hele aangeleentheid van die kwaliteit van die meerdere vergadering is nie direk uit die Skrif afleesbaar nie. Sover vasgestel kon word, gee die Skrif self nie 'n duidelike uitspraak of die meerdere vergadering 'n vergadering van gemeentes (kerke, soos die Gereformeerde Doleansie-kerkreg dit stel), 'n vergadering van die ampte of 'n vergadering van ampsdraers is nie. Maar die beslissing in hierdie verband hang wel direk saam met die leer van die kerk oor die locus de ecclesia.

Dit kan dus alleen uitgemaak word nadat die omvang en draagkrag van die Skriftuurlike beginsels oor die regering van die kerk, soos hierbo genoem, vasgestel is. Dit kan natuurlik óók gebeur dat die genoemde Skriftuurlike beginsels, soos onder andere saamgevat in die belydenisskrifte, aanvaar, bely en geleer word, maar dan nié in die kerklike orde weerspieël word nie. So gebeur dit in ons Kerkwet dat die anti-hiërargiese beginsels in artikel VI wèl gestel word, maar in die Bepalings en in die kerklike praktyk sorgvuldig negeer word. Dit skep die vermoede dat artikel VI slegs vir die doeleindes van versiering in die Kerkwet opgeneem is. Dieselfde kan o.a. ten opsigte van stellings in die NGB, artikel 29 en 31 aangedui word.

Dit laat die vraag ontstaan ò in ons teologiese arbeid binne die kerk en in ons besluite oor die kerklike orde daar 'n bewustheid bestaan oor die samehang tussen Skrif, belydenis en kerkorde en of daar uitgegaan word van die standpunt dat Skrif en kerkorde niks met mekaar te make het nie. Omdat dáároor geen uitspraak van 'n meerdere vergadering bestaan nie, is dit moeilik om vas te stel wat die standpunt is - indien enige.

\section{Die orde van die godsdiensoefening}

Aangesien die godsdiensoefening die hart van die lewe van die kerk 
(= die volk van God) op aarde is, is dit duidelik dat rondom die verkondiging, die belydenis, die gebede, die lofsang en die viering van die sakramente en oor die getal, die aard en inhoud van die sakramente daar duidelikheid in die ruimte van die kerk moet wees. Artikel 30 NGB gee hier die gróót riglyne en andermaal is dit duidelik dat hier ' $n$ vermenging van presiese Skrituurlike aanwysings en menslike afleidings èn reëlings is.

So kan daarop gewys word dat die vraag of die doop by wyse van besprenkeling of onderdompeling moet plaasvind 'n redelike steriele maar tog voortdurende gesprek binne en langs die kerk moontlik gemaak het. Net so het bepaalde reëlings rondom die nagmaal ook al heelwat kontroverse uitgelok sonder dat vanuit die Skrif 'n finale antwoord gegee kan word. Hier kan gedink word aan vrae, soos die hoeveelheid bekers wat gebruik (mag) word, die kelkievraagstuk, om maar nie te praat oor die vraag hoe Christus werklik by die nagmaal teenwoordig is nie.

In die godsdiensoefening gaan dit om die vraag na die praesentia realis Christi èn hoe die godsdiensoefening ingerig móét wees sodat die gelowiges of die volk van God inderdaad God dáár kan en sal ontmoet. Die beslissings wat hier geneem is èn wat uitloop in die ordereëls van die Kerkwet en Bepalings veronderstel ' $n$ duidelike begrip van alles wat hier op die spel is.

Dit is nogal opvallend dat van al die ou Kerkordes wat 'n bydraende rol tot die totstandkoming van ons Kerkwet en Bepalings speel (al is dit dan ook net indirek) slegs die Londonse Christelijke Ordonnancien van 1554 enigsins uitvoerige bepalings oor die orde en vorm van die godsdiensoefening gegee het.

In die Calvinistiese presbiteriaal-sinodale kerklike ordes waar oor hierdie sake gehandel word, is dit meer ordebepalings rondom die godsdiensoefening as reëlings ten opsigte van die godsdiensoefening wat gegee word. Meeste van dié reëlings lê nader aan die ius humanum as enigiets anders. So is dit duidelik dat die kategese van die dooplidmate 'n Skriftuurlike opdrag is en selfs die inhoud van die kategese word aangedui, maar die reëlings rondom die kategese (byvoorbeeld 'n saak soos die ouderdom van die katkisant voor hy toegelaat word om in die openbaar belydenis van geloof af te lê) is weer suiwer ius humanum.

\section{Die handhawing van die dissipline, orde en tug}

Hierdie saak wat ook as één van die nota ecclesiae aangedui word (NGB, art 29), vloei vanselfsprekend voort uit die Skriftuurlike opdrag van prediking en sakramentsbediening èn vanuit die ordening van die volk van God. Oor hierdie saak word ook duidelike 
Skrifaanwysings gevind en ons onderskeid tussen opsig en tug, of die ou onderskeid oor die hantering van heimlike en openbare sondes is suiwer Skriftuurlik. Tog vind ons hier óók 'n vermenging van ius divinum en ius humanum, hoewel oor die feit dát die dissipline gehandhaaf moet word daar duidelike Skriftuurlike aanwysings bestaan.

\section{Wie moet 'n kerkwet opstel?}

Uit die bogenoemde uiteensetting blyk dit dat die kerkwet, dit wil sê die ordereëling wat die lewe van die volk van God op aarde in vaste en ordelike bane lei sodat die ware godsdiens onderhou kan word en die ware leer oral versprei kan word, wèl 'n duidelike Skriftuurlike basis het èn moet hê indien daar ' $n$ samehang tussen Skrif, belydenisskrif en kerklike orde gehandhaaf wil of moet word.

Daar is natuurlik teoloë, waaronder manne van die kwaliteit van Rud Sohm en Emil Brunner, wat baie stellig verklaar dat daar nie 'n verband tussen Skrif en kerkwet kán bestaan nie. Met ander woorde die vraag na die ius divinum in die kerkwet word deur hulle as 'n onsinnige vraag afgewys. Die Calvinistiese vadere, wie se kerkordende arbeid tot 1804 ons kerklike lewe bepaal het, het egter ' $n$ onlosmaaklike verband tussen Skrif, belydenis en kerkorde geleer èn gehandhaaf. Daardie verband is deur die 19de-eeuse kerkregtelike opvattings, wat vanaf 1824 ons kerkregtelike denke en reëls medebepaal, grotendeels ontken en veral die normerende invloed van die belydenisskrif word daardeur sterk afgewys en selfs grotendeels ontken. Dit het die belydenisskrif veral sterk op die agtergrond van die kerklike lewe gestoot. Vanweë die invloed van die 19de-eeuse kerkreg (wat in ons kerk die kerklike orde vanaf 1862-1950 bepaal het) is ' $n$ hele reeks van die beginsels vir die kerklike orde, soos hierbo genoem, genegeer en is geoordeel, deur verskillende sinodale vergaderings, dat 'n meerderheidsbesluit óók 'n regsreël skep vir die kerklike orde, al is daardie reël in stryd met ' $n$ Skriftuurlike beginsel en daarom (in teorie) ultra vires. In ieder geval oor hierdie aangeleentheid het daar ook nog baie min teologiese denkarbeid in ons Kerk plaasgevind en is dit moeilik om vas te stel presies wát die standpunt is. Afgelei uit die praktyk wil dit soms voorkom dat die Skriftuurlike beginsels, soos vasgelê in die belydenisskrifte, as onbelangrik ten opsigte van die kerklike orde beskou word.

As nou, verder gevra word wie 'n Kerkwet moet opstel, is dit duidelik dat ás die kerklike reg as ius sui generis beskou word - en dít word nié allerweë aanvaar nie - dan is dit alleen die kerk self wat 'n kerkwet kan opstel. Vanweë ons bestaande owerheidsreëls waarvolgens die kerk as 'n genootskap of vrywillige vereniging beskou 
word, is daar ook nie juis gevaar dat die owerheid so iets sal wil onderneem nie. Ons owerheid wat in beginsel godsdienstig neutraal is en in die lig van die voorgestelde nuwe grondwetlike bedeling al verder wil wegkom van die beskuldiging dat die staat "Christelik" is, sal in ieder geval géén belangstelling hê in 'n kerkwet nie, tensy so 'n kerkwet die kerkgenootskap die karakter van 'n staatsgevaarlike of ondermynende organisasie gee. Verder is dit duidelik dat die howe ook lede van die kerkgenootskap sal beskerm indien die billikheidsreël, wat vir die juriste so belangrik is, binne die kerklike genootskap oorskry word.

Die kerk self, uitgaande van Joh Calvyn se twee ryke-leer, sien die kerk as 'n eiesoortige corpus langs die owerheid met sy eie reg en oordereël wat op die geopenbaarde waarheid en nié op die natuurreg èn redelike denkvermoë van die mens gebou is nie. Dit beteken dat die kerk die reg opeis om sy eie orde te skep en te handhaaf, of die owerheid dit nou aanvaar of nie.

In die liggaam van die kerk is dit, in die Calvinistiese presbiteriaal-sinodale orde vanselfsprekend dat die kerkwet of kerkorde deur die sinodale vergadering saamgestel moet word omdat alleen in die sinodale vergadering daar ' $n$ toestroming van die regeer-amp in en van die kerk is wat byeenkom om vir die kerk as ' $n$ geheel dié beslissings te neem wat die orde en reël in die geheel van die kerk sal bepaal sodat die ware godsdiens onderhou word en die ware leer oral versprei word.

Dit is ook vanselfsprekend omdat die sinodale vergadering ook die enigste vergadering van die ampte is wat die belydenis vasstel en dus vanuit die Skrif, soos uitgelê deur die belydenisskrif, die kerklike orde èn kerkwet kan vasstel sodat daar (indien gewens) 'n samehang kán bestaan tussen Skrif, belydenisskrif èn kerkwet.

\section{Wat hoort nou tuis in die kerkwet}

In die lig van die voorgaande kan nou die stelling gemaak word (indien 'n samehang tussen Skrif, belydenisskrif en kerkwet aanvaar word) dat die kerkwet altyd èn onder alle omstandighede ' $n$ mengsel sal wees van direkte Skriftuurlike bepalings èn algemeen-aanvaarde afleidings uit daardie Skriftuurlike bepalings wat as ius divinum aangedui kán word. Daarnaas sal daar net soveel indien nie méér menslike bepalings wees wat daarom gemik is om die ius divinum in die praktiese kerklike lewe te laat funksioneer.

Byvoorbeeld: daar bestaan géén twyfel dat die dienswerk van die predikant in die kerk moet bestaan nie. Dit is dus ius divinum. Die reëlings ten opsigte van die studie van 'n kandidaat vir daardie dienswerk, die reëlings ten opsigte van die proponentseksamen en die inhoud daarvan, is alles ius humanum. 
Dit alles wil egter nié sê dat die ius humanum in die kerkwet minderwaardig ten opsigte van die ius divinum is nie. Beide staan in die kerkwet op gelyke voet, behalwe dat die ius humanum nooit die ius divinum as 't ware kan "oortroef" nie. Die omgekeerde is wèl moontlik. Calvyn stel in sy Kommentaar op I Korintiërs 11:12 dat die kerkorde ontstaan vanweë die communi consensu van die lidmate omdat daarvoor geen uitvoerige ordinationes Dei bestaan nie. Want sê hy:

“. ons weet dat elke kerk die vryheid het om vir homself 'n orde van regering (politiae formam) op te stel wat vir daardie kerk paslik en bruikbaar is omdat die Heer nie iets bepaalds voorgeskryf het nie."

Hiervandaan verder kan nou die vraag gestel word of 'n kerkwet 'n minimum of 'n maksimum stel ordereëls moet bevat of nie. In die Calvinistiese presbiteriaal-sinodale kerkordes is gewoonlik daarvoor gekies om 'n minimum aantal ordereëls op te stel. Met ander woorde hier is slegs die groot beginsels van die kerklike orde neergeskryf. Miskien kan daarop gelet word dat die Geneefse Kerkorde van 1561 uit 173 artikels bestaan het. Die huweliksreg, wat in die latere kerkordes wegval, is egter verantwoordelik vir 55 artikels sodat daarsonder die orde slegs 118 artikels het. Die ontwerp-Kerkorde van Wezel 1568 het uit 123 artikels bestaan, maar die 1619-Kerkorde van Dordrecht het maar 86 artikels getel.

Hierdie artikels is normaalweg in vier hoofstukke verdeel, naamlik die dienste of ampte; die vergaderings; die leer en seremonies; die orde en tug, terwyl 'n vyfde hoofstuk ook 'n paar reëlings bevat het wat nie bo ingepas het nie.

Die feit dat die kerkorde slegs die hooflyne van die kerklike orde neerskryf, het nié beteken dat net die ius divinum opgeteken is nie. Reeds hier kry mens die bekende vermenging van ius divinum èn ius humanum. Die nadeel van so 'n beperkte kerkwet is dat die toepassings-in-die-praktyk van dié beginsels deur 'n reeks van sinodale beslissings gereël moet word. Dié reëlings vind mens in Nederland onder die Quaestiones particulares. Dit beteken uiteindelik dat 'n kerkwet/kerkorde saam met 'n uitvoerige kommentaar of samevatting van al dié sinodale beslissings nodig is om dié orde in die praktyk te laat funksioneer.

'n Kerkwet of orde waar die maksimum aantal beginsels saam met reëls gebruik is om die kerklike lewe te reël, is byvoorbeeld die bundel Reglementen wat vanaf 1816 in die Nederlandse Kerk in gebruik was en wat ' $n$ boek van ongeveer 400 bladsye beslaan het. Die Reglement saam met die sinodale beslissings het die kerklike lewe in Nederland gereël tot 1950 toe ' $n$ nuwe kerkwet aanvaar is. 
Die Nederlandse voorbeeld het by ons nie algemene navolging gevind nie, hoewel die Kerkwet wat tot 1950 gegeld het en wat basies die 1869-Wet met wysigings was, tog uit iets meer as 200 artikels bestaan het. Die Nederlandse Kerkwet-wysiging is hier by ons direk nagevolg, sonder dat dit 'n gepaardgaande indringende diskussie oor die beginsels van die kerklike orde, soos dit in ons Kerk verstaan is, tot gevolg gehad het. Selfs die notules van die destydse Raad vir Regsadvies lewer in hierdie verband nie baie materiaal nie. Die indruk bestaan dat die 1951-Wet wat in ons Kerk aanvaar is, so aanvaar is omdat aangeneem is dat alles in Nederland goed deurdink is en dat dit daarom vir ons óók goed sal wees. Die gevolg is dat 'n hele reeks ordereëls aanvaar is wat nie uit ons Kerk se eie verstaan van die Skrif, die belydenisskrif en die kerkordenende beginsels wat ter sake is, voortgekom het nie. Juis omdat hieroor nie baie helderheid bestaan het nie, is daar ook met elke Algemene Kerkvergadering aan die ordening verander en geskaaf, maar omdat die geheel selde of ooit ter sake was en dit meestal om ad hoc-veranderings gegaan het, is dit so dat ons Kerkwet hom op 'n hele paar punte weerspreek. Pogings om dit te elimineer, het nie altyd in die smaak van die meerderheid op ' $n$ Algemene Kerkvergadering geval nie, sodat dié interessanthede of weersprekings rustig bly staan het. Die struktuur van ons Kerkwet is nou dat daar ' $n$ betreklike klein getal Kerkwet-artikels opgeneem is wat ook in ' $n$ sekere sin verskans is in dié sin dat hulle nie so maklik veranderbaar is nie.

Dié Kerkwet-artikels begin met' $n$ omskrywing van wie en wat die kerk is èn wie lidmate van die kerk is en kan wees. Daarna word gehandel oor die ampte, die vergaderings en al die ander reëlings wat die lewe en werk van die kerk as 'n geheel moet reël.

Dan volg die hele reeks Bepalings wat dieselfde regskrag het as 'n gewone besluit van 'n Algemene Vergadering en wat, min of meer, beskou kan word as die uitwerk-vir-die-praktyk van die beginselreëlings wat in die Kerkwet-artikels gegee word. Die enigste reeks Bepalings wat enigermate "verskans" is, is die reëlings in verband met die Pensioenfonds wat, interessant genoeg, volledig as ius humanum beskou kan word.

Die Kerkwet-artikels èn die Bepalings is óók maar weer 'n mengsel van ius divinum en ius humanum. Dit is nié so dat die Bepalings eksklusief die ius humanum bevat en die Kerkwet-artikels eksklusief die ius divinum nie. Dit lyk ook hoogs onwaarskynlik dat so 'n onderskeiding ooit in enige kerkwet gemaak kan word. Daarom is die vraag wát presies tuishoort in 'n kerkwet en wat nie, so moeilik om te beantwoord. Die een groot vraag wat elke kerkorde/kerkwet moet beantwoord, is die vraag hoe die opperhoofskappy van Jesus Christus oor sy liggaam (= die kerk) in die wêreld verwerklik moet word sodat daar nie aan die praesentia realis Christi getwyfel kan 
word nie. Dit gaan dus om die vraag hoe "die geestelike bestuurswyse wat ons Here ons in sy Woord geleer het" (NGB, art 30) in die praktyk moet wees. Dit is, in die lig van die bostaande, nie so enkelvoudig nie.

Enersyds is daar die moontlikheid om slegs die algemene beginsels te stel. Die minimumvereiste wat aan so 'n kerklike orde gestel kan word, is dat dáár gestel sal moet word:

(a) 'n omskrywing van wie en wat die kerk is;

(b) 'n beginselstandpunt oor die feit dat Jesus Christus die enigste Hoof en Heer van die kerk is;

(c) 'n omskrywing van die lidmate - hulle kwaliteit ensovoorts;

(d) 'n omskrywing van die ampte of dienste met daarmee saam die erkenning dat dit Jesus Christus is wat self sy kerk regeer;

(e) 'n omskrywing van die vergaderings èn hulle funksies met daarby die aanduiding wáár die grense van die vergaderings se bevoegdhede lê, (of hiér of onder 2 of 3 sal die antihiërargiese klousule ingevoeg moet word);

(f) 'n omskrywing van die leer, die godsdiensoefening, die gebruik van die sakramente èn wat daarmee saamhang;

(g) 'n omskrywing van hoe die orde-dissipline-tug in die liggaam van Christus gehandhaaf sal word.

In 'n sekere sin sou mens dus kon volstaan met artikels 27-32 van die NGB wat feitlik ál hierdie genoemde sake raakvat. Daarby sou dan noodwendigerwyse 'n volstandige opsomming gegee moet word van al daardie dinge wat ons moet aanneem, "wat kan dien om eendrag en eenheid te bevorder en te bewaar" en ons almal in gehoorsaamheid aan God te hou (art 32, NGB). Nou is die vraag of al daardie sinodale beslissings wat geneem is om hierdie beginsels te láát funksioneer, deel is van ' $n$ corpus van besluite wat ' $n$ kerkwet/ kerkorde genoem word en of dit slegs as 'n "toevoeging" of kommentaar op die kerkwet/kerkorde beskou moet word.

Dit wil voorkom asof dit nie veel verskil sal maak nie, want die regsgeldigheid van ' $n$ sinodale beslissing of ' $n$ bepaling van die kerkwet is presies dieselfde in ons Kerk. Daarom wil dit voorkom dat die huidige konstruksie wat ons het, naamlik ' $n$ kerkwet met betreklik verskanste artikels en 'n reeks bepalings wat dáárdie artikels in die praktyk kan laat funksioneer, goed werk. Daarby moet in ag geneem word dat ál die sinodale besluite óók deel vorm van die totale hoeveelheid materiaal wat die orde in ons Kerk reël.

Andersyds is daar natuurlik die moontlikheid om, soos die 19deeeuse kerkreg gedoen het, álle sinodale besluite oor elke moontlike aspek van die kerklike orde en lewe in één wetboek saam te vat. Die groot nadeel van so ' $n$ uitvoerige ordereëling is dat dán die ius 
humanum makliker die ius divinum kan oorwoeker en die indruk geskep kan word dat dit mènslike kundigheid is wat 'n menslike struktuur en organisasie (= die kerk) bepaal.

Die feit bly egter staan dat die voortdurend veranderende omstandighede èn die feit dat die mens self voortdurend van insig en begrip verander (soos die winde van leringe waai) meebring dat sinodale vergaderings verskillende uitleggings aan sentrale, vasstaande ordereëls vasknoop sodat die corpus van sinodale besluite, rondom die kerklike orde, steeds méér word. Daarom wys die Ned Geref Kerk ' $n$ aktuarius aan om hier tred te hou en te sorg dat soveel as moontlik verhoed word dat botsende besluite geneem of gehandhaaf word.

Uit die voorgaande is dit duidelik dat nòg die Dordtse Kerkorde 1619 nòg die huidige Kerkwet van ons Kerk voldoen aan die vereistes wat hier gestel is. Omdat daar so min oriënteringsmateriaal oor hierdie aangeleentheid binne ons Kerk se teologiese dinkarbeid bestaan, is dit moeilik om vas te stel of die maatstawwe wat hier gestel is in ons kerklike denke aanvaarbaar is of nie.

\section{Slotopmerkings}

'n Probleem in hierdie verband is dat in ons Kerk nêrens ' $n$ uitspraak te vind is van wat onder die begrip ius divinum verstaan moet word nie. In hierdie verband bly dit waar wat Heckel 'n keer gestel het (Joh Heckel, Das blinde undeutliche Wort "Kirche", Ges Aufsätze Köln/ Graz 1964, S659):

"Ein Hauptproblem, ja das kernproblem des Kirchenrechts der christlichen Kirche ist die Frage nach dem ius divinum. Wie immer sie zu beantworten sein mag, so viel ist gewiss: Von der Antwort wird die Stellung der Kirche zum Recht, insbesonderes ihre Auffassung des Kirchenrechts sowie ihr rechtliches Handeln entscheidend bestimmt."

Daarom is dit nie so maklik om sonder meer hierdie saak te beredeneer nie, omdat ' $n$ vraag beantwoord moes word wat in ons Kerk nog nooit werklik aan die orde gestel was nie. 